\title{
Introduction: From Concord to Peace
}

This special issue arose from a workshop on "Peace and Concord from Plato to Lessing", organised by the editors and which took place at the University of Sydney on 18 and 19 September 2017. Central to the work of both the editors is the relationship between the concepts of 'concord', 'peace' and 'dignity' within a setting created by a concern with the development of a philological anthropology. Their work combines both intellectual history and philosophy, ${ }^{1}$ a combination that is reflected in the contents of the special issue of Theoria. The importance of these terms is that they allow for another interpretation of the ethical and the political. Central to both is the location of human being within a larger cultural context. That context demands an approach in which philosophy does not exclude history, and history recognises that it is already informed philosophically. If there is a unifying term, it is 'culture'. The approach taken within the larger project starts with the centrality of culture as that which demands to be thought. ${ }^{2}$ And yet culture is neither tranquil nor unified. As Walter Benjamin argued, there 'is no document of culture which is not at the same time a document of barbarism'. ${ }^{3}$ Allowing for culture's centrality entails a reconfiguration of both philosophy and intellectual history.

The papers published in this special issue are not methodologically the same; nonetheless, they have an important affinity insofar as each can be read as contributing to this larger project. It is a project that, while necessitating the highest level of scholarship, is equally driven by the need to respond to the demands made on thought by events that alter the cultural fabric. When Hannah Arendt wrote in the aftermath of totalitarianism, she argued that dignity needed what she described as a 'new guarantee'. ${ }^{4}$ While her 
claim had a specific location, the aftermath of horrors of civil war, political violence and forms of ethnic cleansing underscore both the necessity and the contemporary force of her argument. 'Dignity' is not, however, a term that stands on its own; it forms part of a collective of terms, including 'peace', 'concord' and 'harmony', all of which are essential to think through how a response to defining moments within the contemporary are both to be and understood and a response developed. Rather than simply invent new meanings for these terms - the contention underpinning the larger historical and philosophical undertaking of which this special issue plays a pivotal role - a beginning can be made by exploring the ways these terms figure within the history of thought. Hence, the strategic purpose of this special issue is to explore the concepts of 'peace' and 'concord' - and thus the complex nature of their relation - in a number of key case-studies selected from the history of European thought.

Both terms - 'peace' and 'concord' - identify, as much within theology and religion as in philosophy, the presence of modes of relationality, for example, the relation between self and other, God and 'man', friend and enemy. However, the strategic importance as well as the originality of the project is that it marks a move away from the explication of relationality and sovereignty in terms that give priority to war. Hobbes' formulation of relationality as 'bellum omnium contra omnes' is the most emphatic expression of this position. What the distancing of war opens up are other possibilities that are available in order to think relationality.

As a beginning, it should be noted that Greek conceptions of

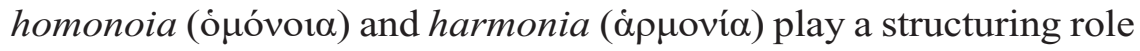
and thus exert an important influence on the later Latin conception of concordia. This is especially the case when Concordia designates a political friendship and also the common good. Hence it is vital to start with the presence of these terms in the Greek context. Neither 'peace' nor 'concord' has an essential quality, the terms denote a constellation of theological and philosophical engagements. The issue will trace those engagements. The presence of 'peace' in Nicholas of Cusa's De pace fidei, for example, grounds the possible sense of commonality between the divergent religions with religion itself and not in the ways in which the administration of religion occurs. Furthermore, Spinoza's contention that 'pax enim non belli privatio, 
sed virtus est' is equally an attempt to rethink the priority of peace. Generally, however, the texts presented, which follow as much a directly philosophical trajectory as one orientated by the history of ideas, are part of a sustained project to develop a philosophical anthropology within which a constellation of the terms 'concord', 'peace', 'harmony' and 'dignity' play a fundamental role.

Rick Benitez's engagement with Plato - 'Plato's Conception of Peace: A Preliminary Exploration' - is not just concerned with Plato's writings on peace; of specific concerns is the precise conception of peace that Plato develops. The article begins with Plato's attitude to war (polemos) and its conventional opposite, peace $($ eirēen $\bar{e}$. In this context there is no direct concern with peace - war predominates. If, however, the focus is moved from war to a different type of conflict, faction (stasis), an important difference then emerges. Plato considers faction unproductive because of the internal divisions it sustains. Yet Plato does not specifically call the opposite of faction 'peace'; instead, he uses terms that have different extensions, such as dikaiosune (justice). Nevertheless, it is possible to outline a positive Platonic conception of peace by tabling a set a of peace-related terms. Benitez distinguishes three categories of terms that describe (1) conditions of peace (or negative peace), (2) dispositions of peacefulness and (3) relations of peace, where such relations result from the expression of peaceful dispositions. The force of his investigation is that it shows that positive peace, for Plato, is founded on the unity and integrity of character. Only when individuals are at peace with themselves can peace within society be achieved.

In his 'The Glorious Excess of Peace in Marsilius of Padua's Defensor Pacis', Richard Lee shows what in Marsilius of Padua grounds the legitimacy of the kingdom or the state (civitas) on the peace that rule provides the citizens. Lee demonstrates that Marsilius carries out this project by trying to locate peace within Christian and biblical thought. He therefore prefaces his thinking of peace with an invocation of glory. Looking at Aristotle's claim that the civitas strives to be like an animal in which all parts are in the right proportion for the sake of the overall health and, thus, well-being of the animal, Marsilius argues that 'the parts of the kingdom or state will be well disposed for the sake of peace [tranquilitas].' Marsilius goes on to define peace as the agreeable 
'belonging together' of all members of the kingdom or the state. In this way, Marsilius moves away from a theological ground of the legitimacy of the state toward one that is entirely secular. However, the ground is an unstable one, though not because it is nontheological but because it acknowledges the fact that the "members" of the body politic are characterised by difference. As the being-together of the different members of the body politic cannot be natural or caused, peace is always that which comes from the outside and, therefore, is glorious.

Andrew Benjamin, in his paper 'Who Were the Faithful? Nicholas of Cusa's De Pace Fidei', is concerned with way that Cusanus' conception of peace is structured by his metaphysical commitments. Early in the De Pace Fidei, unity, as a philosophical topic, is introduced. It is announced in the claim that 'oneness is prior to all plurality'. This is, of course, the condition in terms of which peace is possible. There is in Cusanus a genuine metaphysics of peace that is a certain thinking of difference. Difference is only tolerable precisely because it is a conception of plurality premised on 'oneness'. Harmony (concordia) as an end state - and the text both begins and ends with 'harmony' - could then be read in terms of an act that was staged without being intended. God could be praised by the non-Christian, even though the 'prince of darkness' may have caused the one praising not to understand that, in so doing, it is the 'one' behind the plurality who is in fact the object of praise. Benjamin sketches the limits of Cusanus' metaphysics of peace and, thus, the conception of harmony (concordia) that it envisages.

In his 'From Security to Peace and Concord: The Building of a Free Commonwealth in Spinoza's Political Treatise', Stefano Visentin shows how Spinoza's Theological-Political Treatise deals with the development of a free and pacific commonwealth, taking into account both a confrontation with the Erasmian irenic tradition and the original position of Spinoza's republicanism within the Dutch context of that period. Visentin compares the Spinozistic idea of security with the Hobbesian one in order to demonstrate that in Spinoza (differently from Hobbes) security and freedom are not antithetical but rather support each other. Such a conclusion allows for consideration of the role of peace and concord within the Theological-Political Treatise as the result of a collective process 
of the auto-emendation of social interactions and political institutions. In this perspective, Spinoza's concept of peace appears a very original attempt to build a free political community where democratic institutions are both the cause and effect of pacific (i.e., rational and harmonious, although not necessarily irenic) relationships among citizens.

Daniel Canaris, in 'Peace and Reason of State in the Confucius Sinarum philosophus', argues that persistent feature in Jesuit reports about the late Ming and early Qing was the notion that an enduring peace and concord pervaded the Chinese political system. Although the Jesuits did not invent this association, which was rooted in Greco-Roman historiography, the Jesuit encyclopedist Antonio Possevino (1533-1611) was the first to link the 'perpetual peace' (perpetua pax) and 'supreme concord' (summa concordia) of the Chinese state to the Confucian intellectual tradition. As the Jesuits' missionary strategy developed under the tutelage of Matteo Ricci (1552-1610), 'public peace' (pax publica) and 'the calm of the Republic' (Republica quies) came to be perceived as the ultimate purpose of the Confucian precepts and one of the hinges on which the aims of Christianity, Confucianism and natural law can be reconciled. The supreme expression of the link between Confucianism and peace can be found in the Confucius Sinarum philosophus (1687), which presented for the first time an accessible translation of three of the four Confucian classics. Yet while retaining the view that pre-Qin Confucianism espoused peace as a central political aim, the Confucius Sinarum philosophus challenged the view that contemporary China could be regarded as a utopic actualization of Confucian peace. Canaris' paper interprets this shift as an attempt to co-opt the experience of China as an argument against political philosophy divorced from theism that Jesuit thinkers identified with the reason of state tradition.

Cat Moir, in 'Faith, Reason and Peace in Lessing's Late Works', argues that during the eighteenth century, the struggle between faith and reason was often the source of intense intellectual and political conflict. The German philosopher, essayist, and playwright Gotthold Ephraim Lessing became embroiled in this conflict in the 1770 s when, after publicly criticising Lutheran orthodoxy, was subjected to royal censorship. In the works he produced after this incident Lessing explicitly tries to square revealed faith and 
autonomous reason as both necessary aspects of the pursuit of peace. Moir's paper explores the relation between faith, reason and peace in two of Lessing's works, his 1779 play Nathan the Wise and his 1780 essay The Education of the Human Race. The ring parable in Nathan provides a powerful image of how the exercise of autonomous reason in the interest of a common good is the necessary condition of peaceful competition between established religions. Because there is no objective proof as to the truth of any specific revealed religion for the time being, the faithful are called upon to deliver such proof by acting morally and harmoniously until the end of time. Meanwhile, in The Education of the Human Race, Lessing argues that religious revelation is to the human race what moral education is to the individual human being. In order to achieve peace, however, he argues that human cultures must overcome the specificities of revealed faith to do good for its own sake. Set in this context, Lessing's works are interpreted by Moir as offering a model of how the conflict between faith and reason can be a source of eventual peace.

As noted as the outset, each of the papers presented here offer a sustained engagement with the concepts of harmony, concord and peace. The papers deploy methodologies that include both philosophy and intellectual history. Even then, there are different conceptions of the philosophical and the historical at work with the papers. Taken as a whole, they mark an important moment in which, rather than working with the assumption that war is the only original condition and that, as a result, peace is only ever wars' suspension, the papers begin to open up way of thinking through the possibility that peace, along with harmony and concord, is itself an original condition. Once this position is taken as decisive, it will then have an important impact upon how both the history and the actuality of conflict is understood.

Andrew Benjamin and Francesco Borghesi

Guest Editors

\section{Notes}

1. For indicative work by the editors that forms part of this larger project, see Benjamin 2018 and Borghesi 2018.

2. For a work that is important to the approach undertaken here, see Rubini 2014. 
3. Benjamin 2003.

4. Arendt 1951/2004. For a discussion of this aspect of Arendt's work within the context of the larger project see, Benjamin 2016.

\section{References}

Arendt, H. (1951) 2004. The Origins of Totalitarianism (1951). rev. ed. New York: Schocken Books.

Benjamin, A. 2018. 'Redressing the Metaphysics of Nudity: Notes on Seneca, Arendt and Dignity', Classical Philology 111 (4): 39-52.

Benjamin, A. 2016. 'The Problem of Authority in Arendt and Aristotle', Philosophy Today 60 (2): 253-276.

Benjamin, W. 2003. 'On the Concept of History', in Walter Benjamin, Selected Writings, Vol. 4. Cambridge, MA: Harvard University Press, 389-400.

Borghesi, F. 2018. 'Teologia delle religioni nel Quattrocento. La concordia in Niccolò da Cusa e Giovanni Pico della Mirandola', Filosofia Politica 32 (1): 29-46.

Rubini, R. 2014. The Other Renaissance: Italian Humanism between Hegel and Heidegger, Chicago-London: University of Chicago Press. 